\title{
Karakter morfologi akar sebagai indikator kekurangan air pada tanaman (Root morphological characters as water-deficit indicators in plants)
}

\author{
Nio Song $A i^{(1)^{\star}}$ dan Patricia Torey ${ }^{1)}$ \\ 1) Jurusan Biologi FMIPA Universitas Sam Ratulangi Manado, 95115 \\ `Email korespondensi:nio_ai@yahoo.com
}

Diterima 10 Januari 2013, diterima untuk dipublikasikan 4 Februari 2013

\begin{abstract}
Abstrak
Ketersediaan air tanah yang berkurang serta perubahan iklim yang tidak menentu menyebabkan kekurangan air bagi tanaman. Pada saat kekurangan air akar berperan penting dalam adaptasi tanaman karena akar mampu mengabsorbsi air dengan memaksimalkan sistem perakaran. Beberapa karakter morfologi akar yang menunjukkan resistensi tanaman terhadap kekurangan air ialah pemanjangan akar ke lapisan tanah yang lebih dalam, pertambahan luas dan kedalaman sistem perakaran, perluasan distribusi akar secara horizontal dan vertikal, lebih besarnya berat kering akar pada genotipe tanaman yang lebih tahan kering, pertambahan volume akar, peningkatan berat jenis akar dan resistensi longitudinal pada akar, daya tembus akar yang tinggi, lebih tingginya rasio akar dan tajuk serta rasio panjang akar dan tinggi tanaman.

Kata Kunci: kekeringan, morfologi akar, resistensi
\end{abstract}

\begin{abstract}
The decrease of soil water availability and unpredicted climate change resulted in water deficit in plants. The plant root is very important in plant adaptation during water deficit as the root can absorb the water by maximizing the root system. Some root morphological characters that indicated the drought resistance in plant are root lengthening through deeper soil layers, the increase of root area and depth, the increment of horizontal and vertical root distribution, bigger root dry mass in droughtresistant genotypes, increased root volume, the increase of root density and longitudinal resistance, bigger root penetration, higher root shoot ratio, and also larger ratio of root length and plant height.

Keywords: drought, resistance, root morphology

\section{PENDAHULUAN}

Selama siklus hidupnya tanaman memperoleh air dengan cara menyerap air dari lingkungannya. Yang dipengaruhi oleh faktor lingkungan dan faktor tanaman. Faktor lingkungan yang berpengaruh adalah kandungan air tanah, kelembaban udara dan suhu tanah. Faktor tanaman yang berpengaruh adalah efisiensi perakaran, perbedaan

tekanan difusi air tanah ke akar, dan keadaan protoplasma tanaman (Nofyangtri 2011).

Kekurangan air merupakan salah satu faktor pembatas utama di bidang pertanian yang dapat mempengaruhi proses pertumbuhan dan perkembangan serta hasil produksi tanaman. Ketersediaan air tanah yang semakin menurun serta adanya perubahan iklim yang tidak
\end{abstract}


menentu menyebabkan kemarau yang berkepanjangan dan selanjutnya mengakibatkan kekurangan air pada tanaman (Efendi 2009). Di samping itu kekurangan air pada tanaman dapat terjadi karena laju hilangnya air akibat transpirasi terjadi lebih cepat dibandingkan dengan laju pengambilan air dari tanah. (Nio dan Banyo 2011).

Sebagai salah satu organ tanaman, akar berperan penting pada saat tanaman merespons kekurangan air dengan cara mengurangi laju transpirasi untuk menghemat air. Pada umumnya tanah mengering dari permukaan tanah hingga ke lapisan tanah bawah selama musim kemarau. Keadaan ini menghambat pertumbuhan akar di lapisan tanah yang dangkal, karena sel-selnya tidak dapat mempertahankan turgor yang diperlukan untuk pemanjangan. Akar yang terdapat di lapisan tanah lebih dalam masih dikelilingi oleh tanah yang lembab, sehingga akar tersebut akan terus tumbuh. Dengan demikian sistem akar akan memperbanyak diri dengan cara memaksimumkan pemaparan air tanah (Campbell et al. 2003).

Berbagai karakter fisiologi, anatomi dan morfologi, telah dievaluasi sebagai respons tanaman terhadap kekurangan air. Salah satu karakter penting untuk dievaluasi adalah morfologi akar, karena kemampuan akar mengabsorbsi air dengan memaksimalkan sistem perakaran merupakan salah satu pendekatan utama untuk mengkaji kemampuan adaptasi tanaman terhadap kekurangan air (Efendi 2009). Tanaman dengan volume akar yang besar akan mampu mengabsorbsi air lebih banyak sehingga mampu bertahan pada kondisi kekurangan air (Palupi dan Dedywiryanto 2008). Tanaman yang mengembangkan sistem perakaran yang dalam dapat mengekstrak air di lapisan tanah yang lebih dalam (Passioura 2002), seperti nilam yang memanjangkan akarnya untuk mencari air (Djazuli 2010), panjang akar padi yang lebih toleran lebih besar daripada padi yang relatif tidak toleran akibat induksi kekurangan air dengan PEG 6000 (Suardi 2002). Peningkatan panjang dan volume akar merupakan respons morfologi yang penting dalam proses adaptasi tanaman terhadap kekurangan air (Budiasih 2009). Di samping itu makin besar diameter akar makin besar tingkat toleransi tanaman padi terhadap kekurangan air (Suardi 2002). Perlakuan kekurangan air pada uji toleransi kapas terhadap kekurangan air menunjukkan bahwa kekurangan air mempengaruhi pertumbuhan kecambah, khususnya berat kering kecambah (Jadid 2007).

Berdasarkan pokok-pokok pikiran di atas, pembahasan dalam makalah ini akan difokuskan pada beberapa karakter morfologi akar yang dapat dipakai sebagai indikator resistensi tanaman terhadap kekurangan air, seperti panjang akar, perluasan dan kedalaman sistem perakaran, distribusi akar, berat kering akar, volume akar, berat jenis akar dan resistensi longitudinal pada akar utama, daya tembus akar, rasio akar dan tajuk serta rasio panjang akar dan tinggi tanaman.

\section{DAMPAK KEKURANGAN AIR PADA TANAMAN}

Air merupakan komponen yang sangat vital bagi tanaman karena dibutuhkan dalam jumlah yang besar untuk pertumbuhan dan perkembangan tanaman. Kehilangan air pada jaringan tanaman akan menurunkan turgor sel, meningkatkan 
konsentrasi makromolekul serta senyawa-senyawa berberat molekul rendah yang terakumulasi serta mempengaruhi membran sel dan potensial air sel tanaman. Karena air berperan penting bagi tanaman, maka secara langsung ataupun tidak langsung kekurangan air dapat mempengaruhi semua proses metabolisme tanaman yang selanjutnya menurunkan pertumbuhan tanaman (Anonim 2012c).

Kebutuhan air setiap tanaman berbeda, tergantung pada jenis tanaman dan fase pertumbuhannya (Solichatun et al. 2005). Hal ini juga berkaitan langsung dengan proses fisiologis dan morfologis pada tanaman serta kombinasi kedua faktor tersebut dengan faktor-faktor lingkungan. Kebutuhan air pada tanaman dapat terpenuhi dengan adanya penyerapan air oleh akar. Jumlah air yang diserap oleh akar sangat bergantung pada kandungan air tanah, kemampuan partikel tanah untuk menahan air serta kemampuan akar untuk menyerap air (Nio et al. 2010).

Kemampuan akar untuk menyerap air beserta unsur-unsur hara yang terlarut di dalamnya dipengaruhi oleh faktor genetis, kemampuan akar untuk mentranslokasikan unsur-unsur tersebut dari akar menuju ke daun serta kemampuan akar untuk menyebarkan atau memperluas sistem perakaran ke jarak yang lebih jauh untuk memperoleh suplai hara (Harjadi dan Yahya 1988). Tanaman sering mengalami kekurangan air terutama pada saat musim kemarau, karena pasokan air di daerah perakaran berkurang dan laju evapotranspirasi yang melebihi laju absorbsi air oleh tanaman (Solichatun et al. 2005).
Kekurangan air pada tanaman terjadi akibat keterbatasan air di lingkungannya, termasuk pada media tanam (Jadid 2007). Kekurangan air pada tanaman dapat disebabkan karena tanaman kekurangan suplai air di daerah perakaran dan permintaan air yang berlebihan oleh daun akibat laju evapotranspirasi yang melebihi laju absorpsi air walaupun keadaan air tanah tersedia cukup (Mathius et al. 2001).

Respons tanaman terhadap kekurangan air dapat dilihat berdasarkan aspek fisiologi, morfologi, tingkat pertumbuhan, dan juga produktivitas. Pertumbuhan sel merupakan fungsi tanaman yang paling sensitif terhadap kekurangan air. Kekurangan air pada tanaman akan mempengaruhi turgor sel sehingga akan mempengaruhi pertumbuhan dan perkembangan sel, sintesis protein, dan sintesis dinding sel (Solichatun et al. 2005). Tanaman yang mengalami kekurangan air umumnya memiliki ukuran yang lebih kecil dibandingkan dengan tanaman yang tumbuh normal. Kekurangan air dapat menurunkan hasil produksi tanaman yang sangat signifikan dan bahkan bisa menjadi penyebab kematian pada tanaman (Nio dan Banyo 2011). Berkurangnya produktivitas (biomassa) tanaman pada saat kekurangan air disebabkan oleh penurunan aktivitas metabolisme primer termasuk fotosintesis dan penyusutan luas daun. Penurunan akumulasi biomassa akibat kekurangan air untuk setiap jenis tanaman bervariasi tergantung pada respons masing-masing jenis tanaman terhadap kekurangan air (Solichatun et al. 2005). 


\section{KARAKTER MORFOLOGI AKAR SEBAGAI KEKURANGAN \\ TANAMAN INDIKATOR}

Respons tanaman terhadap kekurangan air (resistensi terhadap kekeringan) dapat dilakukan dengan beberapa mekanisme yaitu drought escape, dehydration avoidance dan drought tolerance. Drought escape (tahan kekeringan) merupakan kemampuan suatu tanaman untuk menyelesaikan siklus hidupnya sebelum terjadi kekeringan yang cukup serius. Mekanisme ini meliputi perkembangan fenologi yang cepat dan plastisitas perkembangan (Jones et al. 1981, Jordan et al. 1983), sehingga tanaman menghasilkan sedikit pertumbuhan vegetatif, sedikit bunga dan sedikit biji di lingkungan dengan kekeringan yang parah. Jika curah hujan tinggi, tanaman menghasilkan pertumbuhan vegetatif, bunga dan biji yang lebih banyak (Jones et al. 1981).

\section{Dehydration}

avoidance

(menghindar dari kekeringan) memungkinkan tanaman untuk menghindari dehidrasi jaringan dengan mempertahankan potensial air daun yang tinggi selama periode kekeringan (Jones et al. 1981). Mekanisme ini mencakup pengurangan kehilangan air dan mempertahankan pengambilan air (Jones et al. 1981, Jordan et al. 1983). Kehilangan air dapat dikurangi dengan peningkatan resistensi stomata; pengurangan luas daun akibat penuaan dan orientasi, daun yang menggulung; peningkatan epicuticular wax; peningkatan resistensi kutikula (O'Toole et al. 1979, Jordan et al. 1983). Pengambilan air dapat dipertahankan dengan kedalaman atau densitas akar yang meningkat, sehingga tanaman dapat mengakses air tanah dengan volume yang lebih besar (Kamoshita et al. 2000, 2004). Resistensi hidrolik yang tinggi pada tanaman (Jones et al. 1981, Jordan et al. 1983) juga memungkinkan pengambilan air terus berlangsung, karena (1) saluran xilem yang sempit pada akar memaksa tanaman untuk memanfaatkan air tanah secara lebih perlahan-lahan (Passioura 1972; Richards 2006) dan (2) akar dapat mendistribusikan air hujan ke daerah yang lebih kering pada lapisan tanah yang lebih dalam sebelum evaporasi dari permukaan tanah terjadi (Reynolds et al. 2005).

Drought tolerance (toleransi terhadap kekeringan) memungkinkan tanaman untuk bertahan terhadap kekeringan pada potensial air jaringan yang rendah, yaitu dengan mempertahankan turgor dan/atau toleransi terhadap dehidrasi (Jones et al. 1981, Jordan et al. 1983). Turgor dapat dipertahankan dengan penyesuaian osmotik, peningkatan elastisitas selular dan penurunan ukuran sel. Toleransi terhadap kekeringan menguntungkan kelulushidupan tanaman pada saat kekeringan (Turner 1979), yang tergantung pada kemampuan tanaman untuk mengatasi luka mekanis, kemampuan membran untuk mengatasi degradasi, dan kemampuan membran dan sitoplasma untuk mengatasi denaturasi protein.

Mekanisme morfofisiologis tanaman untuk menghindar dari kekurangan air adalah kemampuan tanaman untuk mencari sumber air jauh dari permukaan tanah pada saat terjadi kekurangan air di daerah dekat permukaan tanah. Kemampuan tersebut tidak dapat dilepaskan dari karakter morfologi akar. Karakter morfologi akar akan mempengaruhi satu atau lebih komponen hasil 
produksi, karena hal ini berkaitan erat dengan jumlah air yang dikumpulkan oleh akar, efisiensi air yang dikumpulkan (proses asimilasi pada akar yang mempengaruhi jumlah produksi biomasa untuk tiap satuan jumlah air yang ditranspirasi), indeks pemanenan, serta besarnya kebutuhan air pada tanaman (Passioura 1982). Beberapa karakter morfologi akar yang berkaitan dengan respons tanaman terhadap kekeringan di antaranya panjang akar, perluasan dan kedalaman sistem perakaran, distribusi akar, berat kering akar, volume akar, berat jenis akar dan resistensi longitudinal pada akar utama, daya tembus akar, rasio akar dan tajuk serta rasio panjang akar dan tinggi tanaman.

Panjang akar menunjukkan panjang dari bagian leher sampai ujung akar (Jadid 2007). Pada umumnya tanaman dengan irigasi yang baik memiliki akar yang lebih panjang dibandingkan dengan tanaman yang tumbuh di tempat yang kering. Walaupun demikian, panjang akar berkaitan dengan ketahanan tanaman pada saat terjadi kekurangan air. Hal ini disebabkan karena pada saat kekurangan air, tanaman akan memanjangkan akarnya sampai ke lapisan tanah yang memiliki ketersediaan air yang cukup, sehingga tanaman tersebut dapat bertahan hidup. Tanaman berakar panjang akan memiliki kemampuan yang lebih baik dalam mengabsorbsi air dibandingkan dengan tanaman berakar pendek (Palupi dan Dedywiryanto 2008). Sebagai contoh, tanaman ubi jalar dapat menembus kedalaman tanah dengan memanjangkan akarnya lebih dari $2 \mathrm{~m}$ untuk mendapatkan air pada saat kemarau yang panjang (Djazuli 2010). Sifat tahan kering pada tanaman padi, dapat dilihat dari sistem perakaran
Nio dan Torey, Karakter morfologi .... 35

yang panjang (Junaıı 1yyz). Pengujian toleransi kekeringan pada 6 genotipe padi gogo yaitu 3 genotipe toleran kekeringan dan 3 genotipe peka kekeringan menunjukkan bahwa genotipe toleran (Salumpikit, B11597C-TB-2-24, dan B11338F-TB26) yang disiram 3 hari sekali memiliki rataan akar terpanjang $(13,82 \mathrm{~cm})$ dan pada genotipe peka (IR65907-116- 1B-MR-4, B528B-TB-12-1-1, dan IR 20) memiliki rataan akar sepanjang 11,63 cm (Satria et al. 2010).

Tanaman yang mengalami kekurangan air memiliki kemampuan mengambil air secara maksimal dengan perluasan dan kedalaman sistem perakaran yang meningkat. Pada saat kekurangan air, genotipe padi yang toleran kekeringan akan mampu mengambil air secara maksimal dengan meningkatkan perluasan dan kedalaman sistem perakaran. Sistem perakaran yang efisien akan meningkatkan laju pengangkutan dan jumlah air yang diangkut ke tajuk, mengurangi kehilangan air melalui epidermis serta mengurangi penyerapan panas melalui penggulungan atau pelipatan daun (Supijatno 2012).

Distribusi akar pada tanaman bervariasi dan hal ini akan mempengaruhi kemampuan tanaman untuk mencukupi kebutuhan airnya. Pada saat kekurangan air, akar akan tumbuh lebih panjang, lebih halus, memiliki banyak cabang. Kekurangan air pada beberapa varietas padi gogo meningkatkan distribusi akar yang lebih merata baik secara horizontal maupun secara vertikal. Distribusi akar pada beberapa varietas padi gogo (Mentik, Sentani, IR 64, Ketan Gudel dan Cempo Gondrol) yang diairi sebanyak $25 \%$ kapasitas lapang meningkat secara horizontal maupun vertikal dibandingkan dengan tanaman yang disiram sampai 100\% 
kapasitas lapang. Hal tersebut disebabkan karena akar akan berusaha memperluas distribusi perakaran dan menembus daerahdaerah yang memiliki persediaan air yang lebih banyak, yaitu pada lapisan tanah yang lebih dalam. Distribusi akar seperti ini akan meningkatkan kemampuan tanaman untuk mencukupi kebutuhan air (Kurniasih dan Wulandhany 2009).

Penurunan ketersediaan air tanah menurunkan berat kering akar. Berat kering akar adalah berat akar setelah dikeringkan di oven pada suhu $70{ }^{\circ} \mathrm{C}$ selama 72 jam sampai beratnya konstan seperti pada akar rumput gajah dan rumput raja. (Sinaga 2008). Genotipe tanaman yang memiliki berat kering akar lebih tinggi pada saat kekurangan air memiliki resistensi kekeringan yang lebih besar (Palupi dan Dedywiryanto 2008). Penelitian Satria et al. (2010) menunjukkan berat kering genotipe padi gogo yang toleran terhadap kekurangan air (Salumpikit, B11597C-TB-2-24, dan B11338F-TB-26) 2 kali lebih besar (2,74 mg) daripada genotipe yang peka (varietas IR65907-116- 1-B-MR4, B528B-TB-12-1-1, dan IR 20). Genotipe tanaman dengan berat kering akar lebih besar pada saat kekurangan air memiliki resistensi terhadap kekurangan air yang lebih besar (Palupi dan Dedywiryanto 2008).

Volume akar pada tanaman menurun sebagai respons terhadap kekurangan air. Perlakuan penggenangan, penggenangan berkala dan tanpa penggenangan menunjukkan bahwa volume akar beberapa varietas padi sawah pada perlakuan penggenangan (103,33 ml) lebih besar dibandingkan dengan perlakuan tanpa penggenangan (74,17 $\mathrm{ml}$ ) pada saat 8 minggu setelah tanam (Astuti 2012).
Peningkatan berat jenis akar dan resistensi longitudinal pada akar utama sangat penting untuk penyerapan air ke dalam tubuh tanaman. Berat jenis akar sangat menentukan kemampuan akar untuk mengekstrak air dari lapisan tanah yang terdekat. Jika lapisan tanah yang dalam itu basah, berat jenis akar yang besar $\left(>0,5 \quad \mathrm{~cm} / \mathrm{cm}^{3}\right) \quad$ akan memudahkan ekstraksi air. Resistensi longitudinal ini berkaitan dengan ukuran pembuluh xilem utama pada akar seminal tanaman. Resistensi longitudinal pada akar utama itu mempengaruhi laju pengangkutan air dari lapisan tanah yang dalam oleh akar melalui lapisan tanah bagian atas yang kering menuju tajuk (Passioura 1982).

Daya tembus akar yang tinggi dapat meningkatkan penyerapan air pada tanah yang lebih keras (Suardi dan Abdullah 2003). Daya tembus akar menunjukkan kemampuan akar untuk menembus lapisan tanah. Lapisan tanah yang semakin dalam dan semakin keras akan mempengaruhi pertumbuhan akar serta penyerapan air dan unsur-unsur hara. Pemberian lapisan campuran lilin dan parafin pada bagian bawah media beberapa galur padi sawah generasi menengah menunjukkan bahwa akar tanaman padi akan berusaha memanjangkan akarnya dan berusaha menembus lapisan tersebut untuk mencari air. Besarnya daya tembus akar pada lapisan tanah yang keras dapat meningkatkan penyerapan air di lapisan tanah yang dalam (Suprihatno dan Suardi 2007).

Pada saat kekurangan air pertumbuhan sistem perakaran umumnya meningkat, sedangkan pertumbuhan tajuk menurun. Tanaman yang lebih mementingkan pertumbuhan akar daripada pertumbuhan tajuk, akan memiliki 
Nio dan Torey, Karakter morfologi .... 37

kemampuan yang lebih baik untuk bertahan pada kondisi kekurangan air. Rasio akar tajuk yang besar umumnya dimiliki oleh varietas padi gogo yang tahan kering dibandingkan dengan varietas padi sawah (Suprianto 1998). Rasio akar tajuk merupakan perbandingan antara pertumbuhan tajuk dan pertumbuhan akar (Solichatun 2005). Besarnya rasio akar tajuk berkaitan dengan kemampuan absorbsi air oleh tanaman yang meningkat sebagai salah satu mekanisme untuk mempertahankan potensial air yang tetap tinggi pada saat tanaman mengalami kekurangan air (Palupi dan Dedywiryanto 2008).

Rasio panjang akar dan tinggi tanaman juga dapat digunakan sebagai indikator adanya kekurangan air pada tanaman. Di antara 140 galur padi sawah yang diteliti, 5 galur padi sawah yang tahan kering memiliki rasio panjang akar dan tinggi tanaman yang lebih besar dibandingkan dengan galur lainnya (Suprihatno dan Suardi 2007). Perlakuan kekurangan air yang diinduksi dengan PEG 8000 pada padi Mira 1 dan IR64 menunjukkan rasio panjang akar seminal dan panjang tunas pada IR64 dengan perlakuan PEG -0,5 $\mathrm{MPa}$ cenderung lebih besar dibandingkan dengan pada Mira1 serta perlakuan PEG 0 MPa (Nio et al. 2010). Lebih besarnya rasio panjang akar dan tinggi tanaman pada varietas padi yang tahan kering menunjukkan bahwa varietas tersebut memiliki sistem perakaran yang memungkinkan tanaman mampu menyerap air untuk memenuhi kebutuhannya pada saat kekurangan air (Suprihatno dan Suardi 2007).

\section{KESIMPULAN}

Karakter morfologi akar yang potensial untuk menunjukkan resistensi tanaman terhadap kekurangan air ialah pemanjangan akar ke lapisan tanah yang lebih dalam, pertambahan luas dan kedalaman sistem perakaran, perluasan distribusi akar secara horizontal dan vertikal, lebih besarnya berat kering akar pada genotipe tanaman yang lebih tahan kering, pertambahan volume akar, peningkatan berat jenis akar dan resistensi longitudinal pada akar, daya tembus akar yang tinggi, lebih tingginya rasio akar dan tajuk serta rasio panjang akar dan tinggi tanaman.

\section{DAFTAR PUSTAKA}

Anonim (2012c) http://pertanian.untagsmd.ac.id/.../Peranan

Air_bagi_Pertumbuhan_Tana man. Diakses pada 24 Oktober 2012

Astuti DN (2012) Pengaruh sistem pengairan terhadap pertumbuhan dan produktivitas beberapa varietas padi sawah (Oryza sativa L.). Tesis. IPB, Bogor

Budiasih (2009) Respon tanaman padi gogo terhadap cekaman kekeringan. Ganec Swara Edisi Khusus 3(3): 22-27

Campbell NA, Reece JB, Mitchell LG (2003) Biologi. Jilid ke-dua. Edisi ke-lima. Erlangga, Jakarta

Djazuli M (2010) Pengaruh cekaman kekeringan terhadap pertumbuhan dan beberapa karakter morfo-fisiologis tanaman nilam. Bul Littro. 21(1): 8-17

Efendi R (2009) Metode dan karakter seleksi toleransi genotipe jagung terhadap cekaman 
kekeringan. Tesis. FMIPA, Bogor

Harjadi S S, Yahya S (1988) Fisiologi stress lingkungan. IPB, Bogor

Jadid MN (2007) Uji toleransi aksesi kapas (Gossypium hirsutum L.) terhadap cekaman kekeringan dengan menggunakan polietilena glikol (PEG) 6000 Skripsi. Fakultas Sains dan Teknologi Universitas Islam Negeri Malang, Malang

Jones MM, Turner NC, Osmond CB (1981) Mechanisms of drought resistance. Dalam: Paleg LG, Aspinall D (ed) The physiology and biochemistry of drought resistance in plants, Academic Press, Sydney, pp 15-37

Jordan WR, Dugas WR, Shouse PJ (1983) Strategies for crop improvement for drought-prone regions. Agric Water Manag 7: 281-299

Junaidi (1998) Indikasi ketahanan padi gogo (Oryza sativa I.) terhadap kekeringan berdasarkan viabilitas benih dan kandungan prolin bebas. Skripsi. IPB, Bogor

Kamoshita A, Wade LJ, Yamauchi A (2000) Genotypic variation in response of rainfed lowland rice to drought and rewatering. III. Water extraction during the drought period. Plant Prod Sci 3:189-196

Kamoshita A, Rodriguez R, Yamauchi A, Wade LJ (2004) Genotypic variation in response of rainfed lowland rice to prolonged drought and rewatering. Plant Prod Sci 7:406-420

Kurniasih B, Wulandhany F (2009) Penggulungan daun, pertumbuhan tajuk dan akar beberapa varietas padi gogo pada kondisi cekaman air yang berbeda. Agrivita 31(2): 118128

Mathius NT, Wijana G, Guharja E (2001) Respons tanaman kelapa sawit (Elaeis guineensis Jacq.) terhadap cekaman kekeringan. Menara Perkebunan 69(2): 29-45

Nio SA, Banyo Y (2011) Konsentrasi klorofil daun sebagai indikator kekurangan air pada tanaman. Jurnal IImiah Sains 11(2): 166173

Nio SA, Tondais SM, Butarbutar $R$ (2010) Evaluasi indikator toleransi cekaman kekeringan pada fase perkecambahan padi (Oryza sativa I.). Jurnal Biologi 14(1): 50 - 55

Nofyangtri S (2011) Pengaruh cekaman kekeringan dan aplikasi mikoriza terhadap morfo-fisiologis dan kualitas bahan organik rumput dan legum pakan. Tesis. IPB

O'Toole JC (1982) Adaptation of rice to drought-prone environments. Dalam: Drought resistance in crops with emphasis on rice. IRRI. Los Baños, Philippines, pp 195-213

Palupi ER, Dedywiryanto Y (2008) Kajian karakter toleransi cekaman kekeringan pada empat genotipe bibit kelapa sawit (Elaeis guineensis Jacq). Bul Agron 36(1): 24-32

Passioura, JB (1982) Drought resistance in crops with emphasis on rice. International Rice Research Institute. Los Banos

Passioura, JB (2002) Environmental biology and crop improvement. Func Plant Biol 29:537-546

Reynolds MP, Mujeeb-Kazi A, Sawkins M (2005) Prospects for utilising plant-adaptive mechanisms to improve wheat 
and other crops in droughtand salinity-prone environment. Ann Appl Biol 146:239-259

Richards RA (2006) Physiological traits used in the breeding of new cultivars for water-scarce environments. Agric Water Manag 80:197-211

Satria A, Suwarno FC, Suwarno (2010) Pengujian toleransi kekeringan padi gogo (Oryza sativa) pada stadia awal pertumbuhan. Makalah Seminar Departemen Agronomi dan Hortikultura Fakultas Pertanian. Institut Pertanian Bogor

Sinaga R (2008) Keterkaitan nisbah tajuk akar dan efisiensi penggunaan air pada rumput gajah dan rumput raja akibat penurunan ketersediaan air tanah. Jurnal Biologi Sumatera 3(1): 29-35

Solichatun, Anggarwulan E, Mudyantini W (2005) Pengaruh ketersediaan air terhadap pertumbuhan dan kandungan bahan aktif saponin tanaman ginseng Jawa (Talinum paniculatum Gaertn.). Biofarmasi 3(2): 47-51

Suardi D (2002) Perakaran padi dalam hubungannya dengan toleransi tanaman terhadap kekeringan dan hasil. Jurnal Litbang Pertanian 21(3): 100-108

Suardi D, Abdullah B (2003) Padi liar tetua toleran kekeringan. Buletin Plasma Nutfah 9 (1): 33-38

Supijatno (2012) Studi mekanisme toleransi genotipe padi gogo terhadap cekaman ganda pada lahan kering di bawah naungan. Disertasi. Institut Pertanian Bogor. Bogor

Suprianto E (1998) Evaluasi beberapa varietas dan galur padi pada kondisi kekeringan. Skripsi. IPB. Bogor

Suprihatno B, Suardi D (2007) Kemampuan tembus akar galur-galur padi sawah generasi menengah. Apresiasi hasil penelitian padi. www.litbang.deptan.go.id/speci al/padi/bbpadi_2008_p2bn2_0 5.pdf. Diakses pada 28 September 2012

Turner NC (1979) Drought resistance and adaptation to water deficits in crop plants. Dalam: Mussell $H$, Staples RC (ed) Stress physiology in crop plants. John Wiley and Sons, New York. $p$ 344-372 